\title{
Juvenile Obesity Enhances Emotional Memory and Amygdala Plasticity through Glucocorticoids
}

\author{
Chloé Boitard, ${ }^{1,2}$ Mouna Maroun, ${ }^{3}$ Frédéric Tantot, ${ }^{1,2}$ Amandine Cavaroc, ${ }^{1,2}$ Julie Sauvant, ${ }^{1,2}$ Alain Marchand, ${ }^{4,5}$ \\ Sophie Layé, ${ }^{1,2}$ Lucile Capuron, ${ }^{1,2}$ Muriel Darnaudery, ${ }^{1,2}$ Nathalie Castanon, ${ }^{1,2}$ Etienne Coutureau, ${ }^{4,5}$ \\ (D) Rose-Marie Vouimba, ${ }^{4,5}$ and Guillaume Ferreira ${ }^{1,2}$ \\ ${ }^{1}$ INRA, Nutrition and Integrative Neurobiology, UMR 1286, 33076 Bordeaux, France, ${ }^{2}$ Université de Bordeaux, Nutrition and Integrative Neurobiology, \\ UMR 1286, 33076 Bordeaux, France, ${ }^{3}$ Sagol Department of Neurobiology, Faculty of Natural Sciences, University of Haifa, Haifa 31905, Israel, ${ }^{4}$ CNRS, \\ Institut de Neurosciences Cognitives et Intégratives d'Aquitaine, UMR 5287, 33076 Bordeaux, France, and 5Université de Bordeaux, Institut de \\ Neurosciences Cognitives et Intégratives d'Aquitaine, UMR 5287, 33076 Bordeaux, France
}

In addition to metabolic and cardiovascular disorders, obesity is associated with adverse cognitive and emotional outcomes. Its growing prevalence during adolescence is particularly alarming since recent evidence indicates that obesity can affect hippocampal function during this developmental period. Adolescence is a decisive period for maturation of the amygdala and the hypothalamic-pituitaryadrenal (HPA) stress axis, both required for lifelong cognitive and emotional processing. However, little data are available on the impact of obesity during adolescence on amygdala function. Herein, we therefore evaluate in rats whether juvenile high-fat diet (HFD)-induced obesity alters amygdala-dependent emotional memory and whether it depends on HPA axis deregulation. Exposure to HFD from weaning to adulthood, i.e., covering adolescence, enhances long-term emotional memories as assessed by odor-malaise and tone-shock associations. Juvenile HFD also enhances emotion-induced neuronal activation of the basolateral complex of the amygdala (BLA), which correlates with protracted plasma corticosterone release. HFD exposure restricted to adulthood does not modify all these parameters, indicating adolescence is a vulnerable period to the effects of HFD-induced obesity. Finally, exaggerated emotional memory and BLA synaptic plasticity after juvenile HFD are alleviated by a glucocorticoid receptor antagonist. Altogether, our results demonstrate that juvenile HFD alters HPA axis reactivity leading to an enhancement of amygdala-dependent synaptic and memory processes. Adolescence represents a period of increased susceptibility to the effects of diet-induced obesity on amygdala function.

Key words: adolescence; amygdala; emotion; glucocorticoids; memory; obesity

\section{Introduction}

Obesity, primarily attributable to overconsumption of energydense food, is considered one of the most serious public health challenges. Indeed, it is associated with cardiovascular diseases, metabolic disorders, and cancers, causing disability and premature death (Malnick and Knobler, 2006; World Health Organization, http://www.who.int/mediacentre/factsheets/fs311/en/). Obesity also affects brain function and induces cognitive disturbances, including impairments of declarative memory, attention, or executive functioning (Nilsson and Nilsson, 2009; Sellbom

\footnotetext{
Received July 29, 2014; revised Jan. 23, 2015; accepted Jan. 28, 2015

Author contributions: C.B., M.M., A.M., S.L., L.C., M.D., N.C., E.C., R.-M.V., and G.F. designed research; C.B., M.M., F.T., A.C., J.S., R.-M.V., and G.F. performed research; C.B., M.M., F.T., A.C., A.M., R.-M.V., and G.F. analyzed data; C.B., M.M., A.M., L.C., M.D., N.C., E.C., R.-M.V., and G.F. wrote the paper.

This work was supported by a PhD grant from AXA Research Fund (C.B.), Grant "Emergence de Jeune Equipe INRA 2010-2012" (G.F.), and Grant LABEX BRAIN ANR-10-LABX-43 (C.B. and G.F.). We thank P. Trifilieff, S. Tronel, and C. Dawson for help with the final text and P. Birac and M. Cadet for technical assistance and for taking care of the animals.

The authors declare no competing financial interests.

Correspondence should be addressed to Guillaume Ferreira, Nutrition and Integrative Neurobiology (NutriNeuro), INRA 1286, Université de Bordeaux, Bâtiment UFR Pharmacie, 146 rue Léo Saignat, 33076 Bordeaux, France. E-mail: guillaume.ferreira@bordeaux.inra.fr.

DOI:10.1523/JNEUROSCI.3122-14.2015

Copyright $\odot 2015$ the authors $\quad 0270-6474 / 15 / 354092-12 \$ 15.00 / 0$
}

and Gunstad, 2012; Francis and Stevenson, 2013). Obesity has also been associated with adverse emotional outcomes, especially with increased anxiety and depression (Hawkins and Stewart, 2012, Dixon et al., 2013), as well as with a higher prevalence of emotional disorders such as post-traumatic stress disorder (PTSD; Pagoto et al., 2012; Johannessen and Berntsen, 2013), which is linked to enduring and maladaptive emotional memory (Elzinga and Bremner, 2002; Layton and Krikorian, 2002). However, a thorough examination of the effects of obesity on emotional memory is still lacking.

Albeit most of the studies on the effect of high-fat diet (HFD) on cognitive and emotional functions focused on adult individuals, overweight and obese adolescents also exhibit cognitive and emotional alterations (Cserjési et al., 2007, Li et al., 2008). The prevalence of obesity in adolescents is still increasing at an alarming rate (Ogden et al., 2012). This is particularly worrisome since adolescence is a period of neurobehavioral shaping required for lifelong cognitive processing (Spear, 2000) that is particularly sensitive to environmental challenges, like excessive food intake (Andersen, 2003; Vendruscolo et al., 2010). We recently demonstrated in animal models that juvenile obesity induced by HFD consumption impaired hippocampal function, in particular spatial and relational memories (Boitard et al., 2012, 2014). However, the 
same HFD exposure restricted to adulthood did not induce such effects (Boitard et al., 2012, 2014), suggesting that adolescence represents a vulnerable period for the effect of HFD on memory. Here, we hypothesized that, similarly to hippocampal-dependent memory, emotional memory could be highly vulnerable to juvenile HFD exposure.

Emotional control of behavior critically depends on amygdala (Fanselow and Gale, 2003; LeDoux, 2003; Maren, 2005). In particular, the basolateral amygdala (BLA) modulates long-term aversive memory (McGaugh, 2004) under the influence of glucocorticoid hormones, the final product of the hypothalamic-pituitary-adrenal (HPA) axis (Roozendaal et al., 2009; Finsterwald and Alberini, 2014). The amygdala and the HPA axis show parallel maturational processes during late childhood and adolescence (Spear, 2000; McCormick and Mathews, 2010; Foilb et al., 2011). Importantly, obesity is associated with HPA axis deregulation in humans (Pasquali et al., 2006), and chronic HFDinduced obesity in animals alters HPA axis function (Legendre and Harris, 2006; Sharma and Fulton, 2013; Tannenbaum et al., 1997). Therefore, the emotional disturbances observed in obese adults could result from diet-induced perturbations during late development of the neural circuits controlling emotional behaviors. The present study directly addresses this issue. We show that HFD-induced obesity during adolescence has a major neurocognitive effect on emotional behaviors. Moreover, our data reveal a causal link between changes in the modulation of amygdala plasticity by glucocorticoids and HFD-induced increase in emotional memory.

\section{Materials and Methods}

Procedures were performed in accordance with French (Directive 87/ 148, Ministère de l'Agriculture et de la Pêche) and international (Directive 86/609; November 24, 1986; European Community) legislation and were approved by the local ethical committee (agreement number 5012047-A).

\section{Animals and diets}

Wistar naive male rats (Janvier), aged either 3 weeks (juvenile group) or 12 weeks (adult group) when they arrived, were housed in groups of two to four individuals in polycarbonate cages $(48 \times 26 \times 21 \mathrm{~cm})$ in a climatized $\left(22 \pm 1^{\circ} \mathrm{C}\right)$ room maintained under a $12 \mathrm{~h}$ light/dark cycle (lights on at 8:00 A.M., lights off at 8:00 P.M.). They had ad libitum access to food and water from their arrival until they were killed. Food provided since their arrival was either a control diet (CD) offering $2.9 \mathrm{kcal} / \mathrm{g}$ (consisting of $2.5 \%$ lipids and $60 \%$ carbohydrate, mostly from starch; A04, SAFE) or a high-fat diet offering $4.7 \mathrm{kcal} / \mathrm{g}$ [consisting of $24 \%$ lipids ( 45 $\mathrm{kcal}$ ), mostly saturated fat from lard, and $41 \%$ carbohydrates ( $35 \mathrm{kcal}$ ); D12451, Research Diets]. One week before behavioral experiments, rats were housed individually (cage, $35 \times 23 \times 19 \mathrm{~cm}$ ) and handled by the experimenter. All rats were exposed to CD or HFD for 4 months starting either at weaning (3 weeks old; jCD and jHFD groups), i.e., exposure throughout adolescent development (from weaning to adulthood; Spear, 2000), or at adulthood (12 weeks old; aCD and aHFD groups), i.e., with the clear exclusion of adolescence (Fig. 1A). All behavioral experiments were performed after 3 months of HFD exposure, and rats were killed after 4 months of diet exposure. One group was exposed to either CD or HFD, starting at weaning, for only 1.5 months before the behavioral experiment. Animals were weighed once per week from their arrival until they were killed. The metabolic status of the animals was evaluated by measuring plasma cholesterol, triglycerides, insulin, and leptin using specific kits (cholesterol RTU and triglycerides enzymatique PAP 150; Biomérieux) or milliplex (rat serum adipokine kit; Millipore). The blood glucose level was assessed after a $24 \mathrm{~h}$ food deprivation by tail nick using Accu-Check devices (sensitivity, 10 mg/dl; Roche Diagnostics).

\section{Effects of juvenile and adult HFD intake on conditioned odor} aversion, auditory fear conditioning, and anxiety-like behavior Conditioned odor aversion. Conditioned odor aversion (COA) results from the association of an odorized tasteless solution [conditioned stimulus (CS)] with a visceral malaise [unconditioned stimulus (US)]. Rats were acclimated to a water-deprivation regimen for $4 \mathrm{~d}$. Access to water was provided in a graded bottle (with $0.5 \mathrm{ml}$ accuracy) placed in the rats' home cage for 15 min each day between 9:00 and 11:00 A.M. Baseline water consumption was obtained by averaging the intake of the last 3 days. On day 5, rats had access for 15 min to almond- or banana-scented water composed of $0.01 \%$ benzaldehyde or isopentyl acetate, respectively, diluted in tap water (Sigma; Sevelinges et al., 2009). After a delay of $30 \mathrm{~min}$, rats received an intraperitoneal injection of the visceral malaiseinducing drug lithium chloride (LiCl; Sigma; $25 \mathrm{mg} / \mathrm{kg}, 0.075 \mathrm{M}, 0.75 \%$ of body weight) or saline ( $\mathrm{NaCl}, 0.15 \mathrm{M}, 0.75 \%$ of body weight). On days 6 and 7 , rats had access to water for $15 \mathrm{~min}$ each day to re-establish baseline water intake. Finally, on day 8, long-term memory of the odor aversion was assessed by providing access to the almond-scented water for $15 \mathrm{~min}$, immediately followed by $15 \mathrm{~min}$ of water. In some experiments, rats underwent 2 other days of testing similar to the first one to verify that animals extinguished the aversion. The percentage of scented water consumption with respect to water baseline was used as a measure of neophobia during acquisition and aversion strength during the test.

In another experiment, short-term memory of COA was assessed $4 \mathrm{~h}$ after odor-malaise association, as described previously (Desgranges et al., 2008). The procedure was identical to the one described above for $\mathrm{COA}$ with the exception that rats were trained to take a water ration twice per day in their home cages: each morning, they had access to $10 \mathrm{ml}$ of tap water during a $15 \mathrm{~min}$ period, and then $4.5 \mathrm{~h}$ later they had ad libitum access to water for $15 \mathrm{~min}$. On day 5 , rats had a restricted access to $10 \mathrm{ml}$ (instead of ad libitum access) of almond-scented solution for $15 \mathrm{~min}$. After a delay of $30 \mathrm{~min}$, rats received $\mathrm{LiCl}$ injection, and $4 \mathrm{~h}$ later they were confronted again with almond-scented water, followed by tap water. This procedure allows enhancing liquid consumption during the short-term memory test (Ferreira et al., 2002; Desgranges et al., 2008).

Auditory fear conditioning. This procedure is based on the pairings of an auditory tone (CS) with electric footshocks (US). Fear conditioning was realized in cages $(40 \times 30 \times 35 \mathrm{~cm}$; Imetronics $)$ located in soundproof chambers with $55 \mathrm{~dB}$ constant noise and diodes promoting constant light. Tones $(5000 \mathrm{~Hz}, 70 \mathrm{~dB})$ lasted $10 \mathrm{~s}$, and electric footshocks $(0.3 \mathrm{~mA}, 6 \mathrm{~Hz}, 1 \mathrm{~s})$ were delivered during the last second of the tone, from a constant-current generator to the stainless steel grid of the floor of each chamber. On day 1 , rats were placed in "context A" cages for $8 \mathrm{~min}$ during which they received five CS-US pairings (intervals were 120, 60, $80,40,100$, and $80 \mathrm{~s}$ ). On day 2 , rats were re-exposed to the context $\mathrm{A}$ for 10 min without any tone or footshock, allowing testing for contextual fear conditioning. Rats were then placed in "context B" for $25 \mathrm{~min}$ (made triangular by the addition of an opaque plastic slab in the diagonal of the chamber with modified patterns on the walls and a rough plastic slab covering the grid floor) and re-exposed to the $10 \mathrm{~s}$ tone without footshocks every $5 \mathrm{~min}$ after an initial $5 \mathrm{~min}$ tone-free period. Rats' behavior during all sessions was recorded through a camera connected to a monitor allowing automatic analysis of freezing response (Marchand et al., 2003), i.e., total immobility except for movements related to breathing (Blanchard and Blanchard, 1969).

Anxiety-like behavior and locomotor activity. One to 2 weeks before fear conditioning, rats were tested in the open-field task and in the elevated plus maze between 9:00 and 11:00 A.M. The open-field apparatus was made of a white wooden box $(100 \times 100 \times 50 \mathrm{~cm})$ without bedding litter and placed in a brightly lit room (60 lux in its center), which constitutes an anxiogenic setup. Each experimental rat was placed facing the wall in a corner of the open field and allowed free exploration for $10 \mathrm{~min}$. A camera wired to an automated tracking system (SMART version 2.5.20; Panlab) was used to track the rat's locomotion in the open field. Using the software, the open field was divided in a central and peripheral zone in which total distance covered and time spent were analyzed. The elevated plus maze was assessed $5 \mathrm{~d}$ after the open-field test. The elevated plus maze apparatus was a black plastic maze made of four arms $(12 \times 50$ $\mathrm{cm})$; two of the arms were closed with walls $(45 \mathrm{~cm}$ high) providing 
shelter. Open arms were anxiogenic since the maze was placed $60 \mathrm{~cm}$ above the floor in a bright light room (60 lux in its center). Rats were placed in the center facing an open arm and allowed free exploration for $5 \mathrm{~min}$. Time spent in each arm and the number of entries in each arm were recorded. A percentage of open-arm entries with respect to the total number of entrances (open plus closed arms) was calculated.

\section{Effects of juvenile and adult HFD intake on amygdala neuronal activation}

Since $\mathrm{LiCl}$ injection induces neuronal activation in the amygdala (Yamamoto et al., 1997; Koh et al., 2003; Ferreira et al., 2006), we measured c-fos and Egr-1 expressions in the central amygdale (CeA) and BLA nuclei. Rats were given injections of a lethal dose of pentobarbital sodium ( $1 \mathrm{ml}$, i.p.) $90 \mathrm{~min}$ after an intraperitoneal injection of saline or $\mathrm{LiCl}$ $(0.075 \mathrm{M}$; Sigma; $0.75 \%$ of body weight, $25 \mathrm{mg} / \mathrm{kg})$. They were then perfused with 0.1 м PBS ( $\mathrm{pH} 7.4$ ), followed by $4 \%$ paraformaldehyde (PFA) in PBS. Brains were quickly removed and stored at $4^{\circ} \mathrm{C}$ in a $4 \%$ PFA for $24 \mathrm{~h}$ to allow postfixation. The next day, they were submerged in a $30 \%$ sucrose solution at $4^{\circ} \mathrm{C}$ for $48 \mathrm{~h}$ to allow cryoprotection. Finally, brains were frozen in isopentane and stored at $-80^{\circ} \mathrm{C}$. Coronal sections of 40 $\mu \mathrm{m}$ were incubated in PBS containing 3\% bovine serum albumin (BSA) and $0.5 \%$ Triton (PBS-BSA-T) to block nonspecific binding sites and to facilitate antibody penetration. The sections were also saturated with $0.3 \%$ hydrogen peroxide for $30 \mathrm{~min}$ to eliminate endogenous peroxydase activity. Sections were first incubated with the primary anti-c-Fos antibody (anti-c-Fos rabbit polyclonal antibody, 1:1000 diluted in PBSBSA-T; Santa Cruz Biotechnology) or anti-Egr-1 antibody (anti-Zif rabbit monoclonal antibody, 1:1000 diluted in PBS-BSA-T; Cell Signaling) for $24 \mathrm{~h}$ at $4^{\circ} \mathrm{C}$. Sections were then incubated for $2 \mathrm{~h}$ with the biotinylated secondary antibody (goat anti-rabbit IgG, diluted 1:2000 in PBS for both c-Fos and Egr-1 immunostaining; Vector Laboratories) at room temperature, followed by $1 \mathrm{~h}$ incubation in the avidin-biotinperoxydase complex solution (ABC solution, Vectastain, diluted 1:1000 in PBS; Vector Laboratories). Between each treatment, sections were thoroughly rinsed with PBS. The peroxydase complex was visualized after incubation for $10 \mathrm{~min}$ in a mix containing diaminobenzidine, ammonium chloride, ammonium sulfate, sodium acetate, glucose, and glucose oxydase. Sections were incubated in sodium acetate (twice for 10 $\mathrm{min}$ ) to stop the enzymatic reaction, rinsed in PBS, mounted on gelatincoated slides, dehydrated, and coverslipped. Labeling was quantified bilaterally on four sections spaced $240 \mu \mathrm{m}$ apart and chosen to cover the whole amygdala [2.5-3.4 mm posterior to bregma, according to Paxinos and Watson (1998)]. Each section was photographed using NikonACT-1 software, and labeled cells were counted with ImageJ software on a surface representing $0.85 \mathrm{~mm}^{2}$. Results were expressed for $1 \mathrm{~mm}^{2}$. The number of cells expressing glucocorticoid receptors (GRs) was also measured using a similar immunohistochemical procedure, except that a mouse monoclonal anti-GR antibody (1:500; Abcam) and a biotinylated horse anti-mouse antibody (1:1000; Vector Laboratories) were used.

Effects of juvenile and adult HFD intake on corticosterone release Corticosterone release after gastric malaise or restraint stress. In juvenile and adult exposed rats used to assess amygdala activation, blood was collected transcardially $90 \mathrm{~min}$ after $\mathrm{LiCl}$ or saline injection, i.e., after pentobarbital injection and before cardiac perfusion. In different cohorts of juvenile exposed rats previously used for COA experiments, blood was quickly collected from a tail nick just before and 30, 90, and $180 \mathrm{~min}$ after intraperitoneal injection of $\mathrm{LiCl}(25 \mathrm{mg} / \mathrm{kg}$ ) or restraint stress (in a plastic ventilated tube allowing no movement, for $30 \mathrm{~min}$ ). The area under the curve (AUC) was calculated to search for a global effect.

Basal corticosterone level. Blood was quickly collected from a tail nick of juvenile exposed rats every 2-4 h from 7:00 A.M. to 11:00 P.M. to evaluate the impact of jHFD on HPA circadian activity. In other rats, blood from a tail nick was collected either at the beginning of the inactive (light) phase ( 9:00 A.M., lights on at 8:00 A.M.), corresponding to low corticosterone levels, or at the beginning of the active (dark) phase $(\sim 8: 00$ P.M., lights off at 8:00 P.M.), corresponding to the peak of corticosterone levels.
Corticosterone level measurement. The total corticosterone level was measured, in plasma obtained after centrifugation of the blood samples $\left(10,000 \mathrm{rpm}, 10 \mathrm{~min}, 4^{\circ} \mathrm{C}\right)$, by an in-house radioimmunoassay (described by Richard et al., 2010). Briefly, after absolute ethanol steroid extraction from plasma samples, total corticosterone was measured by competition between cold corticosterone and radioactive corticosterone for a specific anti-corticosterone antibody provided by Dr. H. Vaudry (University of Rouen, Rouen, France). Sensitivity of the technique was $0.3 \mu \mathrm{g} / \mathrm{dl}$ with $10 \%$ variability intra- and inter-assay.

Adrenal glands. The adrenal glands of juvenile exposed rats previously used for fear conditioning were collected (two per animal) and weighed.

\section{Effects of BLA infusion of a GR antagonist on conditioned odor} aversion after juvenile and adult HFD intake

Rats underwent surgery after 2.5 months of diet exposure [starting either at weaning $(n=47)$ or at adulthood $(n=39)]$ to implant cannulae just above the BLA to allow later infusion of a specific GR antagonist, mifepristone (RU486; Sigma), into the BLA. For this purpose, rats were anesthetized $(70 \mathrm{mg} / \mathrm{kg}$ ketamine and $6 \mathrm{ml} / \mathrm{kg}$ xylazine, i.p.) and placed in a stereotaxic frame. Two guide cannulae (7 mm under pedestal, 23 gauge) were implanted bilaterally $2.0 \mathrm{~mm}$ above the BLA $(2.8 \mathrm{~mm}$ posterior to bregma, $5.1 \mathrm{~mm}$ lateral; $5.5 \mathrm{~mm}$ below skull surface; Paxinos and Watson, 1998) and fixed to the skull by dental acrylic cement and surgical screws. Stylets were inserted in the guide cannulae to prevent obstruction. At the end of the surgery, rats were awakened by Antisedan injection $(0.2 \mathrm{ml}$ per rat) and allowed at least 1 week to recover before starting the water-deprivation regimen. Rats were then habituated to be gently held for infusion. The COA procedure was identical to the one described above with the exception that, on the acquisition day, 30 min after receiving odorized water, animals received intra-BLA infusion of either saline or RU486 immediately before the intraperitoneal $\mathrm{LiCl}$ injection. After stylets were removed, infusion needles (30 gauge) were inserted in the guide cannulae, with tips protruding $2 \mathrm{~mm}$ below, i.e., reaching the BLA. Injection needles were connected to Hamilton microsyringes placed in an automated microinfusion pump allowing bilateral delivery $(0.25 \mu \mathrm{l}$ each side, rate of $0.25 \mu \mathrm{l} / \mathrm{min}$ ) of RU486 (diluted in $2 \%$ ethanol in saline to reach a final concentration of $3 \mathrm{ng}$ in $0.25 \mu \mathrm{l})$ or vehicle $(2 \%$ ethanol in $0.25 \mu \mathrm{l}$ of saline). Dose of drug and volume were chosen according to previous findings (Roozendaal and McGaugh, 1997; Donley et al., 2005). Needles remained in the guide cannulae for an additional 1 min after infusion to minimize liquid dragging, and stylets were reinserted into the guide cannulae. After the experiments, rats were killed, and brains were removed. Coronal sections $(40 \mu \mathrm{m})$ were collected around guide cannulae and stained with cresyl violet to determine cannulae placement. Nine rats with unilateral or bilateral cannulae misplacement were discarded from statistical analysis.

\section{Effects of a GR antagonist on amygdala synaptic plasticity after juvenile HFD intake}

The synaptic plasticity of the BLA was explored in vivo in anesthetized animals using long-term potentiation (LTP) induced in the BLA by highfrequency stimulation of the entorhinal cortex. This pathway was chosen because it clearly modulates BLA synaptic plasticity (Yaniv et al., 2003; Vouimba et al., 2004; Mouly and Di Scala, 2006) and participates in COA memory formation (Ferry et al., 1999).

Rats were anesthetized with Equithesin $\left(2.12 \% \mathrm{w} / \mathrm{v} \mathrm{MgSO}_{4}, 10 \% \mathrm{v} / \mathrm{v}\right.$ ethanol, $39.1 \% \mathrm{v} / \mathrm{v}$ propylene glycol, $0.98 \% \mathrm{w} / \mathrm{v}$ sodium pentobarbital, and $4.2 \% \mathrm{w} / \mathrm{v}$ chloral hydrate; $0.3 / 0.5 \mathrm{ml} / \mathrm{kg}$ ) and placed in a stereotaxic frame, with body temperature maintained at $37 \pm 0.5^{\circ} \mathrm{C}$. Briefly, small holes were drilled into the skull to allow the insertion of electrodes into the brain. A recording microelectrode (glass; tip diameter, $2.5 \mu \mathrm{m}$; filled with $2 \mathrm{M} \mathrm{NaCl}$; resistance, $1.4 \mathrm{M} \Omega$ ) was slowly lowered into the BLA (3.1 $\mathrm{mm}$ posterior to bregma; $5.0 \mathrm{~mm}$ lateral; $7 / 7.6 \mathrm{~mm}$ below skull surface). A bipolar $125 \mu \mathrm{m}$ stimulating electrode was implanted in the entorhinal cortex ( $6.5 \mathrm{~mm}$ posterior to bregma; $5.5 \mathrm{~mm}$ lateral; $5.0 / 5.8 \mathrm{~mm}$ below skull surface). The evoked responses were digitized $(10 \mathrm{kHz})$ and analyzed using the 1401+ (Cambridge Electronic Design) and its Spike2 software. Off-line measurements were made on the amplitude of field postsynaptic potentials using averages of five successive responses to a 


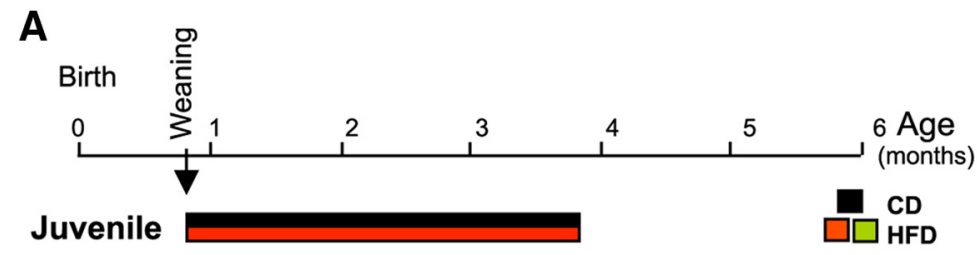

Adult

B

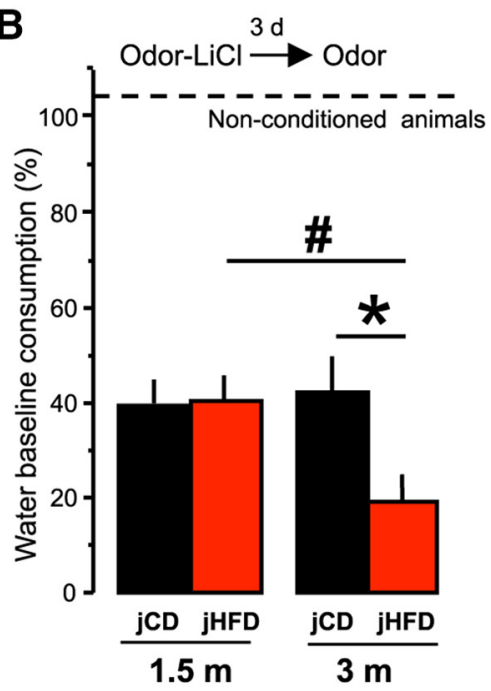

E

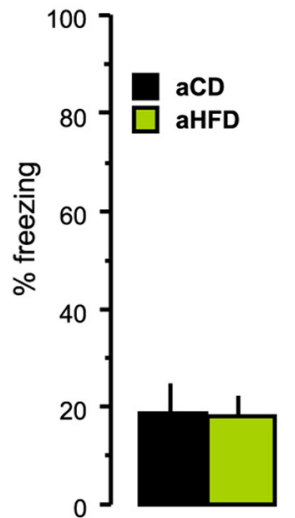

Before

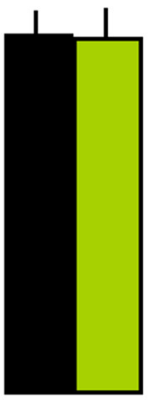

Tone
C
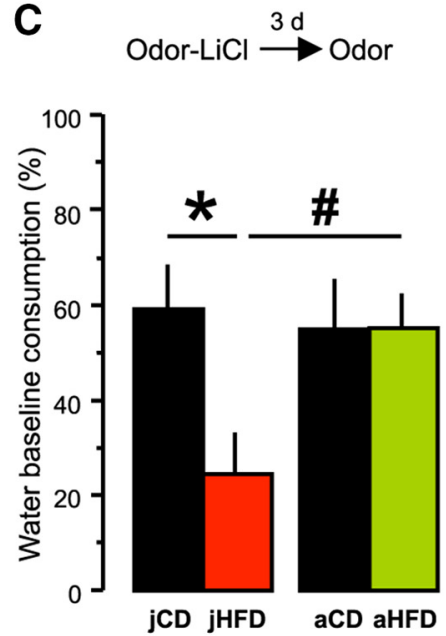

F

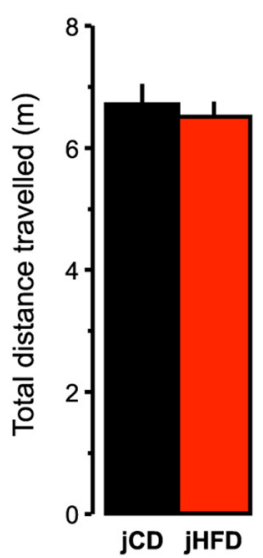

D
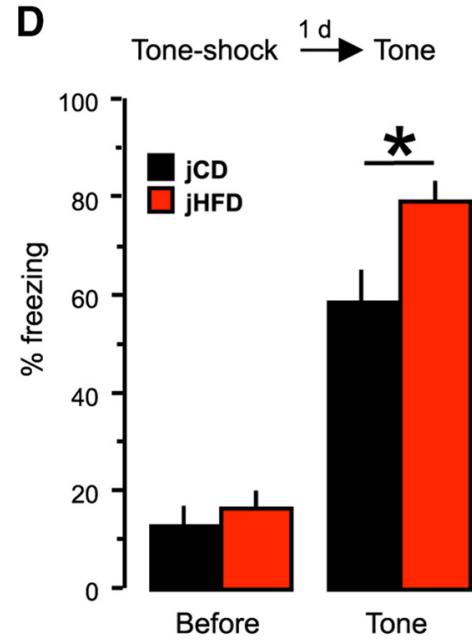

G Elevated plus maze
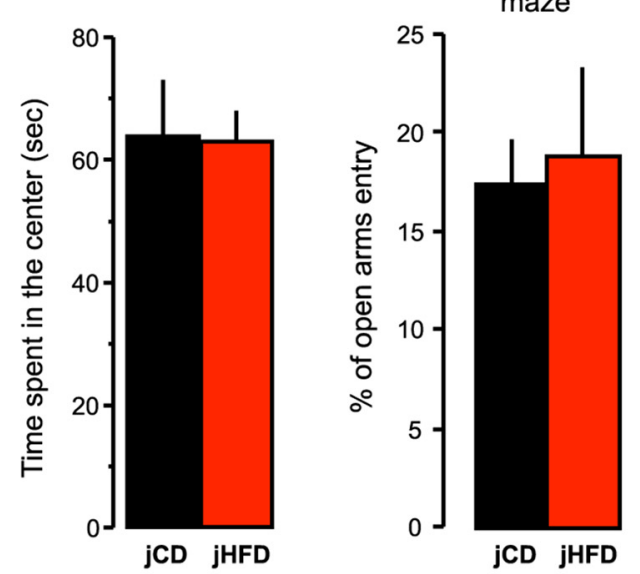

Figure 1. Juvenile, but not adult, HFD exposure enhances odor aversion and auditory fear memories. $\boldsymbol{A}$, Time course of diet exposure in juvenile (starting at weaning) and adult (starting at 3 months of age) rats. $\boldsymbol{B}$, Three months $(3 \mathrm{~m})$, but not 1.5 months $(1.5 \mathrm{~m})$ of HFD consumption starting at weaning, i.e., covering adolescence, enhanced long-term $C 0 A$ memory (jHFD, $n=13$; $j$ CD, $n=12$ for both diet duration). The dashed line represents the odorized water consumption level in nonconditioned animals that received injections of $\mathrm{NaCl}$ (mean for CD an HFD exposure, no diet effect). $\boldsymbol{C}$, Juvenile, but not adult, HFD consumption (for 3 months) enhanced long-term COA memory ( $n=6$ per group). $\boldsymbol{D}$, Juvenile HFD consumption (for 3 months) enhanced auditory fear memory (jHFD, $n=12 ; j C D, n=11$ ). $\boldsymbol{E}$, Adult HFD consumption (for 3 months) had no effect on auditory fear memory (aHFD, $n=13$; aCD, $n=12$ ). The freezing level presented in $\boldsymbol{D}$ and $\boldsymbol{E}$ was obtained before and during the first tone presentation. $\boldsymbol{F}, \boldsymbol{G}$, Juvenile HFD consumption (for 3 months) did not affect anxiety-like behaviors assessed in the open-field test ( $\boldsymbol{F}$ ) and the elevated plus maze ( $\boldsymbol{G}$; jHFD, $n=12 ; \mathrm{jCD}, n=12){ }^{*} p<0.05$ compared with the corresponding $\mathrm{j} C \mathrm{C}$ group; ${ }^{\#} p<0.05$ compared with the $3 \mathrm{~m}$ jHFD group.

given stimulation intensity applied at $0.1 \mathrm{~Hz}$. Test stimuli (monopolar pulses; $100 \mu$ s duration) were delivered at $0.1 \mathrm{~Hz}$. After positioning the electrodes, the rats were left for 30 min before beginning the experiment. LTP was induced in the BLA by theta-like high-frequency stimulation at $100 \mathrm{~Hz}$ (TS-100) to the entorhinal cortex (three sets of 10 trains, each train consisted of 10 pulses at $100 \mathrm{~Hz}$, intertrain interval of $200 \mathrm{~ms}$, interset interval of $1 \mathrm{~min}$ ). For all the experiments, baseline responses were established by means of delivering stimulation intensity $(50-150$ $\mu \mathrm{A}$ ) sufficient to elicit a response representing $\sim 25 / 30 \%$ of the maximal amplitude of the evoked field potentials. Animals received an intraperi- toneal injection (1\% of body weight) of RU486 (50 mg/kg, diluted in ethanol and saline) or vehicle (ethanol and saline) $30 \mathrm{~min}$ before highfrequency stimulation. After the experiments, rats were killed and brains were collected to determine the electrode placement.

\section{Statistical analysis}

Data were expressed as the mean \pm SEM, and statistical analyses were conducted using Statview software with a threshold for considering statistically significant difference being set up at $p \leq 0.05$. The results were analyzed using Student's $t$ tests or two- or three-way ANOVAs with diet 
Table 1. Juvenile and adult HFD exposures induce similar weight gain

\begin{tabular}{|c|c|c|c|c|c|c|}
\hline & $\mathrm{jCD} 1.5 \mathrm{~m}$ & jHFD $1.5 \mathrm{~m}$ & jCD $3 \mathrm{~m}$ & jHFD $3 \mathrm{~m}$ & $\mathrm{aCD} 3 \mathrm{~m}$ & aHFD $3 \mathrm{~m}$ \\
\hline Initial body weight (g) & $54.9 \pm 0.8$ & $54.8 \pm 0.9$ & $54.5 \pm 0.8$ & $54.6 \pm 0.8$ & $496.0 \pm 3.7$ & $489.5 \pm 4.9$ \\
\hline Body weight (g) & $340.5 \pm 6.0$ & $385.8 \pm 9.7^{*}$ & $533.2 \pm 11.3$ & $606.5 \pm 15.5^{*}$ & $689.8 \pm 12.4$ & $762.0 \pm 12.4^{*}$ \\
\hline
\end{tabular}

Shown is body weight on arrival and before assessing behavior, i.e. after 1.5 months (1.5 m) or 3 months ( $3 \mathrm{~m}$ ) of CD or HFD exposure starting at weaning (jCD, jHFD) or at adulthood (aCD, aHFD).

${ }^{*} p<0.05$ compared with the corresponding $C D$ group (unpaired $t$ test).

(CD vs HFD), exposure duration (1.5 vs 3 months), age (juvenile vs adult), injection ( $\mathrm{NaCl}$ vs $\mathrm{LiCl}$ ), and/or drug treatment (RU486 vs vehicle) as between-subject factors and with repeated measurement on the time factor when appropriate. The interactions were further investigated using post hoc Fisher's PLSD tests.

\section{Results}

Juvenile and adult HFD intake induces similar morphometric and metabolic changes

Animals exposed to HFD as juveniles or adults were significantly heavier than their respective controls at the time of behavioral assessment (Table 1), and they had significantly higher circulating levels of leptin (jCD, $8 \pm 1 \mathrm{ng} / \mathrm{ml}$; JHFD, $16 \pm 2 \mathrm{ng} / \mathrm{ml}$; aCD, $9 \pm 1 \mathrm{ng} / \mathrm{ml}$; aHFD, $21 \pm 5 \mathrm{ng} / \mathrm{ml}$ ) but not of insulin, glucose, triglycerides, and cholesterol at the time they were killed [for detailed measurements and statistics, see Boitard et al. (2014)].

\section{Juvenile, but not adult, HFD intake enhances aversion memory}

We first assessed the effects of 1.5 or 3 months of jHFD on COA, a procedure based on odor-malaise pairing highly dependent on BLA integrity (Desgranges et al., 2008; Sevelinges et al., 2009; Fig. $1 A)$. On the acquisition day, the novel almond-scented water was consumed with similar weak neophobic responses in all groups $\left(\sim 80 \%\right.$ of water baseline; duration $\times$ diet effect: $F_{(1,46)}=1.5, p>$ 0.1 ; data not shown). Thirty minutes after, the rats received a mild gastric malaise $(25 \mathrm{mg} / \mathrm{kg} \mathrm{LiCl})$ to induce a moderate aversion. Three days later (long-term memory), all conditioned groups showed reduced consumption of odorized water (compared with water baseline; paired $t$ test: $t>4.6, p<0.001$ for each group; Fig. $1 B$ ). A two-way ANOVA conducted on the four conditioned groups indicated a significant exposure duration $\times$ diet interaction $\left(F_{(1,46)}=4.1, p<0.05\right)$. Post hoc analysis revealed that 3 months of exposure to the jHFD group induced a stronger aversion than the other three groups $(p<0.02)$, which did not differ from one another $(p>0.1$; Fig. $1 B)$. During the next $2 \mathrm{~d}$ of tests, all groups increased their consumption of the odorized water as confirmed by repeated-measures ANOVAs with a significant effect of time $\left(F_{(2,92)}=152.1, p<0.0001\right)$ but no interaction between diet, exposure duration, and time $\left(F_{(2,92)}<1, p>0.1\right)$, indicating a similar extinction rate in all groups (data not shown). We also confirmed that 3 months of jHFD exposure enhanced long-term COA memory using either a different odor CS (banana odor; unpaired $t$ test: jCD, $56 \pm 8 \%$; jHFD, $28 \pm 9 \%$; $t_{(19)}=2.3$, $p<0.05)$ or a different US, the bacterial lipopolysaccharide (250 $\mu \mathrm{g} / \mathrm{kg}$; jCD, $52 \pm 7 \%$; jHFD, $18 \pm 3 \%$; $\left.t_{(14)}=2.5, p<0.05\right)$. Altogether, these results indicate that 1.5 months of $\mathrm{jHFD}$ exposure did not affect COA, whereas 3 months of exposure enhanced long-term COA memory regardless of what CS or US was used.

We then assessed short-term memory by exposing animals to scented water $4 \mathrm{~h}$ after receiving odor-malaise pairing (see Materials and Methods). Both the jCD and jHFD groups showed a similar aversion (jCD, $32 \pm 9 \%$; jHFD, $34 \pm 11 \%$; unpaired $t$ test, $t_{(11)}<1$; data not shown), ruling out the possibility that the stronger aversion seen in the long-term memory test was caused by stronger malaise perception in the jHFD group, and suggest that 3 months of $\mathrm{jHFD}$ exposure specifically enhanced memory consolidation.

To evaluate whether the effect was specific to juvenile exposure, adult rats were submitted to HFD for 3 months before COA acquisition (Fig. 1A). Both groups showed a similar aversion $3 \mathrm{~d}$ later (aCD, $62 \pm 6 \%$; aHFD, $65 \pm 12 \%$; unpaired $t$ test, $t_{(22)}<1$; data not shown). To confirm these data and directly compare the effects of juvenile and adult exposure to HFD on long-term COA memory, we conducted an experiment with four groups: jCD, $\mathrm{jHFD}$, aCD, and aHFD. During the test, a two-way ANOVA indicated an age $\times$ diet interaction $\left(F_{(1,20)}=4.2, p=0.05\right)$; the jHFD group presented a stronger aversion than the other three groups $(p<0.02)$, which did not differ from one another $(p>$ 0.1 ; Fig. $1 C$ ). These results indicate that 3 months of HFD exposure at adulthood did not affect COA, stressing the specificity of jHFD effect on COA.

\section{Juvenile, but not adult, HFD intake enhances auditory fear memory}

Rats were trained in auditory fear conditioning, which is another memory task critically dependent on BLA (for review, see Fanselow and Gale, 2003; Maren, 2005; LeDoux, 2003). Since the experiments were not conducted at the same time, results from juvenile and adult exposed rats are presented and analyzed separately.

We first conducted an experiment with juvenile exposed rats. On the conditioning day, jHFD and $\mathrm{jCD}$ exposed rats showed similar exploratory behavior during the first $2 \mathrm{~min}$ before receiving any CS-US pairings (freezing, $<10 \%$; no diet effect: $t_{(21)}=$ $1.5, p=0.15$; data not shown). After the first CS-US pairing, freezing increased with time until the end of the conditioning session $\left(F_{(1,5)}=41.4 ; p<0.001\right.$ for time effect, no diet or interaction effect; post-shock freezing at the end of the session: $82 \pm$ $4 \%$ and $84 \pm 6 \%$ for jCD and jHFD, respectively). The next day, freezing to the conditioning context was assessed by placing the rats in the same cage without any CS or US. As expected, freezing response was low $(15 \pm 5 \%$ and $13 \pm 2 \%$ for $\mathrm{jCD}$ and $\mathrm{jHFD}$, respectively) and diminished with time, independently of the diet (time effect: $F_{(9,180)}=7.0, p<0.001$, no diet or interaction effect). Freezing to the cue was assessed by exposing rats to the CS in the novel context B. Before being confronted with the first CS, freezing behavior was low and was not affected by the diet $\left(t_{(21)}<\right.$ 1 ; Fig. $1 D$ ). Once the first CS occurred, freezing increased for both groups, but jHFD rats significantly froze more than the jCD group $\left(t_{(21)}=2.73, p=0.012\right.$; Fig. $\left.1 D\right)$, indicating a higher auditory fear memory. Then, freezing decreased during subsequent tone presentations, and at the end of the session there was no effect of diet (jCD, $50 \pm 8 \%$; jHFD, $55 \pm 8 \%$; $t_{(21)}<1$ ).

Concerning adult exposed rats, both the aCD and aHFD groups showed similar exploratory behavior during the first 2 min before CS-US pairings (freezing, $<10 \%$; no diet effect: $t_{(23)}$ $<1$; data not shown). After pairing, freezing increased with time until the end of the conditioning session $\left(F_{(1,5)}=8.65, p<0.001\right.$ for time effect, no diet or interaction effect; postshock freezing at the end of the session: $68 \pm 8 \%$ and $54 \pm 10 \%$ for $\mathrm{aCD}$ and $\mathrm{aHFD}$, 
A

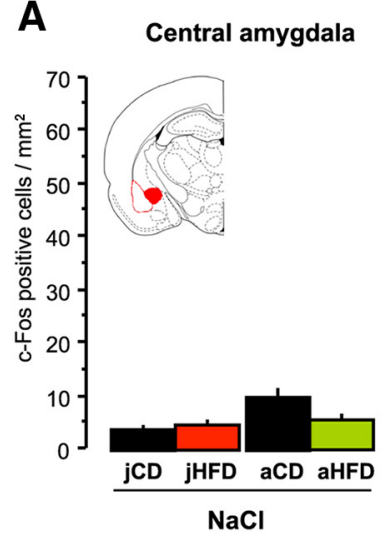

C

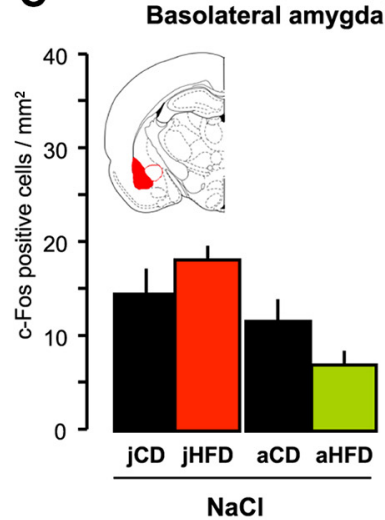

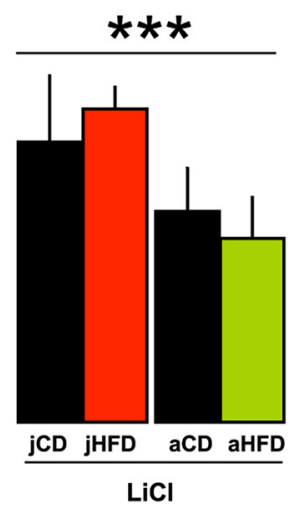

B

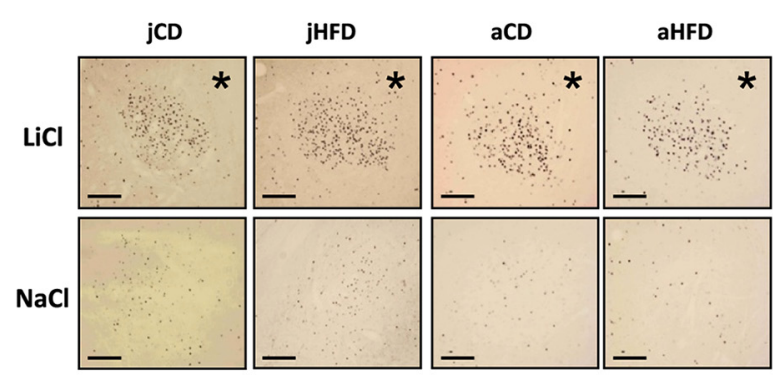

D

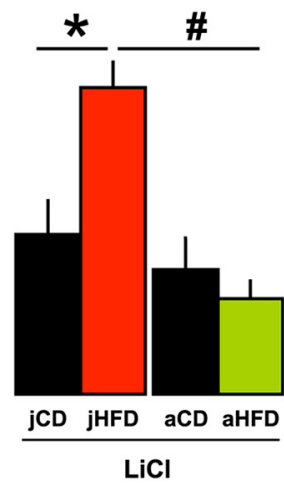

D Basolateral amygdala
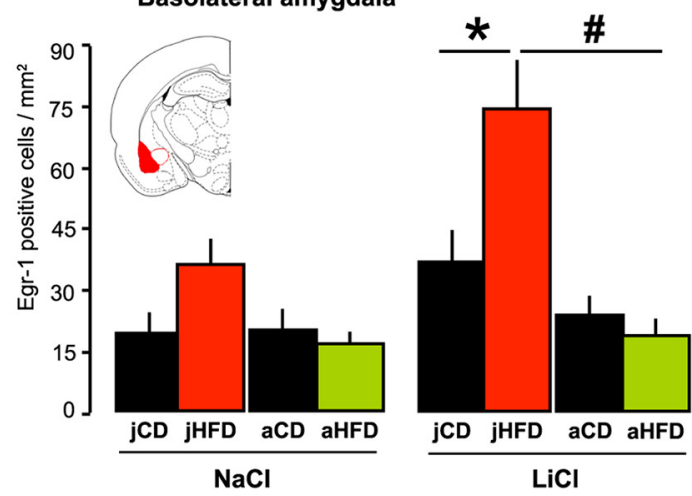

E

jCD

jHFD

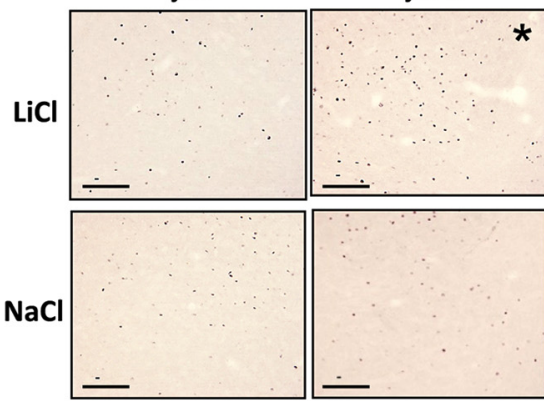

aCD

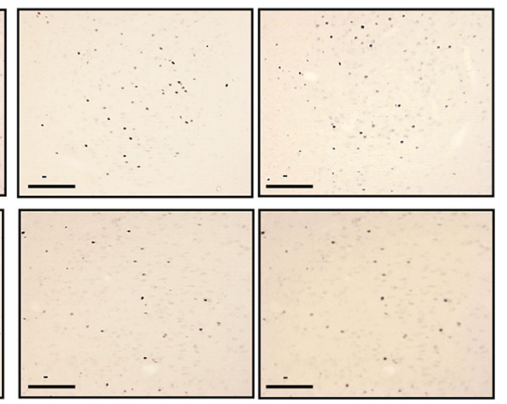

Figure 2. Juvenile, but not adult, HFD exposure enhances basolateral amygdala activation. $\boldsymbol{A}, \boldsymbol{C}, \boldsymbol{D}$, Effects of juvenile or adult $\mathrm{HFD}$ consumption on central amygdala (A) and basolateral amygdala $(\boldsymbol{C}, \boldsymbol{D})$ activation induced 90 min after intraperitoneal injection of $\mathrm{NaCl}$ or $\mathrm{LiCl}(n=6-7$ per group). Amygdala activation was measured by $\boldsymbol{C}-\mathrm{Fos}(\boldsymbol{A}, \boldsymbol{C})$ or Egr-1 (D) labeling. Inset, $\mathrm{Coronal}$ brain sections in $\boldsymbol{A}, \boldsymbol{C}$, and $\boldsymbol{D}$ are adapted from Paxinos and Watson (1998) and depict the regions (in red) in which Fos or Egr-1 expression was analyzed. $\boldsymbol{B}, \boldsymbol{E}$, Representative pictures for c-Fos labeling in central amygdala $(\boldsymbol{B})$ and basolateral amygdala $(\boldsymbol{E})$ after intraperitoneal injection of $\mathrm{NaCl}$ or LiCl in juvenile and adult groups (scale bars, $200 \mu \mathrm{m}$ ). ${ }^{* * *} p<0.001$ compared with NaCl groups; ${ }^{*} p<$ 0.05 compared with the jCD-LiCl group; ${ }^{*} p<0.05$ compared with the jHFD-LiCl group.

respectively). On the test day, freezing to the conditioning context was minimal and comparable across the aHFD and aCD groups (for the entire session: $15 \pm 1 \%$ and $20 \pm 5 \%$ for $\mathrm{aCD}$ and aHFD, respectively; $\left.t_{(22)}<1\right)$. In the novel context $\mathrm{B}$, freezing behavior was low and was not affected by diet before the first CS $\left(t_{(23)}<1\right.$; Fig. $\left.1 E\right)$. Once the first CS occurred, freezing increased for both groups, but no diet effect was present $\left(t_{(23)}<1\right.$; Fig. $\left.1 E\right)$. There were no group differences until the end of the session $\left(\mathrm{aCD}, 60 \pm 7 \%\right.$; aHFD, $53 \pm 8 \%$; $\left.t_{(23)}<1\right)$. These data show that juvenile, but not adult, HFD exposure enhances long-term retention of auditory fear conditioning, another amygdala-dependent memory.

To evaluate whether the enhancement of emotional memory after jHFD exposure results from altered locomotor activity or heightened anxiety-like behaviors, we explored the effects of
jHFD intake on the open-field test and the elevated plus maze. jHFD consumption did not modify the total distance traveled and the time spent in the center of the open field $\left(t_{(22)}<1\right.$; Fig. $1 F)$, nor the percentage of open-arms entry in the elevated plus maze test $\left(t_{(22)}<1\right.$; Fig. $\left.1 G\right)$. It therefore appears that jHFD exposure enhances auditory fear memory without affecting locomotor activity or anxiety-like behavior.

Juvenile, but not adult, HFD intake enhances $\mathrm{LiCl}$-induced basolateral amygdala activation

To evaluate whether the higher COA memory in jHFD-fed rats could be related to higher amygdala activation in response to the aversive stimulus, we assessed neuronal activation using c-Fos and Egr-1 immunohistochemistry in the CeA and BLA of both 
A

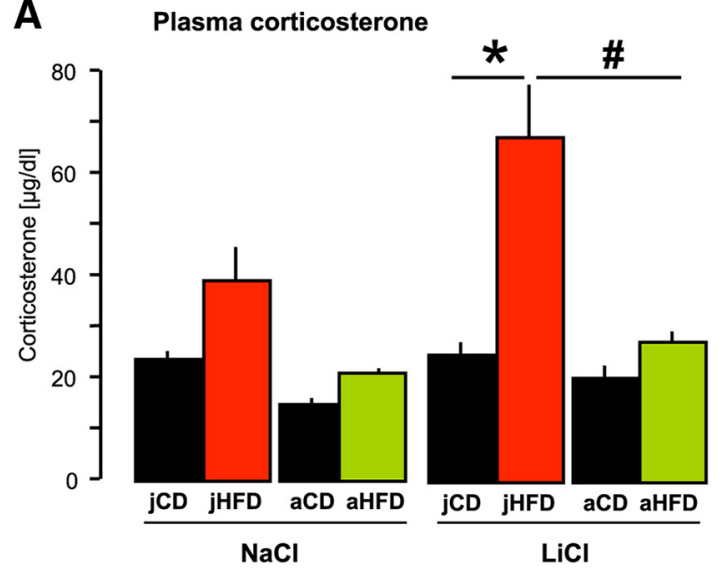

C

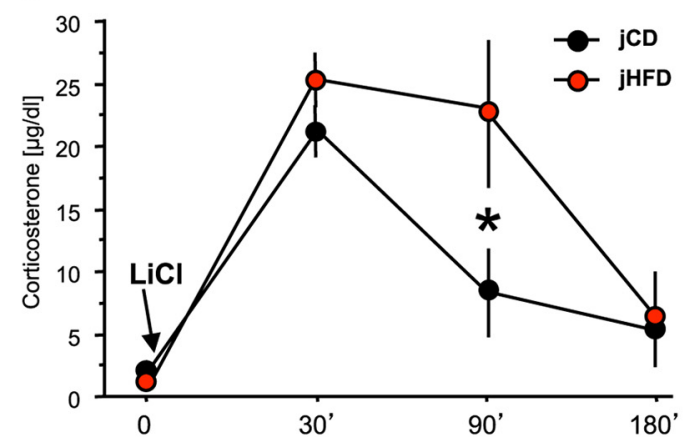

B

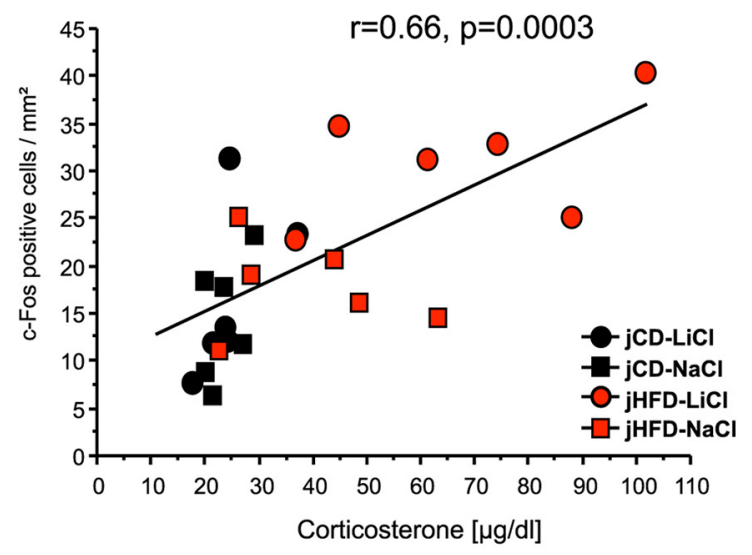

D

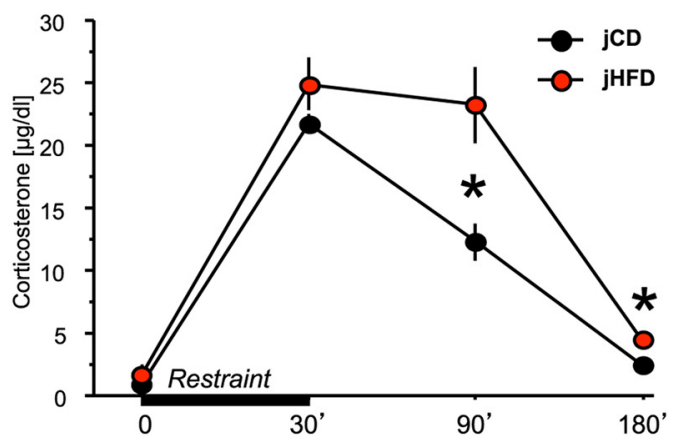

Figure 3. Juvenile, but not adult, HFD exposure enhances corticosterone secretion. $A$, Effects of juvenile or adult HFD consumption on corticosterone secretion induced 90 min after intraperitoneal injection of $\mathrm{NaCl}$ or $\mathrm{LiCl}(n=6-7$ per group). $\boldsymbol{B}$, Correlation between corticosterone secretion and c-fos expression in basolateral amygdala 90 min after LiCl injection in juvenile exposed rats. $C, \boldsymbol{D}$, Effects of juvenile HFD consumption on the dynamic of corticosterone secretion after LiCl injection $(\boldsymbol{C} ; j \mathrm{jHF}, n=7 ; j \mathrm{CD}, n=7)$ or restraint $\operatorname{stress}(\boldsymbol{D} ; j \mathrm{jHF}, n=6 ; j \mathrm{CD}, n=9)$. ${ }^{*} p<0.05$ compared with the jCD-LiCl group; ${ }^{*} p<0.05$ compared with the jHFD-LiCl group.

juvenile and adult exposed animals 90 min after $\mathrm{LiCl}$ or $\mathrm{NaCl}$ injection.

In the CeA, neuronal activation was clearly influenced by $\mathrm{LiCl}$ injection but not by diet (Fig. $2 A 2, B$ ). ANOVA revealed a significant injection effect (c-Fos: $F_{(1,38)}=50.0, p<0.0001$; Egr-1: $\left.F_{(1,38)}=70.9, p<0.0001\right)$ and a significant age $\times$ injection interaction (c-Fos: $F_{(1,38)}=4.1, p<0.05$; Egr-1: $F_{(1,38)}=4.7, p<$ $0.05)$. These data indicate that $\mathrm{LiCl}$ induces strong $\mathrm{CeA}$ activation in all groups with a higher activation in juvenile than in adult groups regardless of the diet (Fig. 2A).

In the BLA, neuronal activation after $\mathrm{LiCl}$ injection was clearly influenced by the age period of HFD exposure (Fig. 2C-E). ANOVA indicated a significant age $\times$ diet interaction (c-Fos: $F_{(1,38)}=12.4, p<0.001$; Egr-1: $\left.F_{(1,38)}=9.0, p<0.005\right)$. This interaction was significant in LiCl-injected groups (c-Fos: $F_{(1,19)}=$ $7.6, p=0.01$; Egr-1: $\left.F_{(1,19)}=5.6, p<0.03\right)$ but only close to significant in NaCl-injected groups (c-Fos and Egr-1: $F_{(1,19)}=3.9, p=$ 0.06). Post hoc analyses indicated that $\mathrm{LiCl}$ injection in the jHFD group induced a significantly higher BLA activation than the other LiCl-injected groups $(p<0.01)$, which did not differ from one another $(p>0.1$; Fig. $2 C, D)$.

Then, we examined whether the stronger BLA activation of jHFD-fed rats could be related to a differential expression of GR in the BLA. However, the number of GR-positive cells in BLA was not different between the jCD and jHFD groups (jCD-NaCl: $30.9 \pm 3.7$ cells $/ \mathrm{mm}^{2}$, jCD-LiCl: $36.6 \pm 3.3$ cells $/ \mathrm{mm}^{2}$, jHFDNaCl: $37.4 \pm 4.3$ cells/mm ${ }^{2}$ and jHFD-LiCl: $35.8 \pm 3.6$ cells/ $\mathrm{mm}^{2}$; no effect of diet, LiCl or interaction: $F_{(1,21)} \leq 3, p \geq 0.1$ ).
Juvenile, but not adult, HFD intake prolongs LiCl-induced corticosterone release

Given that glucocorticoid hormones clearly modulate amygdala function (Roozendaal et al., 2009), we first compared corticosterone levels $90 \mathrm{~min}$ after $\mathrm{LiCl}$ or saline injection in both juvenile and adult exposed rats. $\mathrm{LiCl}$ induced a higher level of plasma corticosterone in the jHFD group than in the jCD group. This effect did not occur in the aHFD and aCD groups (Fig. $3 A$ ). These observations were confirmed by a three-way ANOVA showing a significant diet $\times$ age interaction $\left(F_{(1,40)}=12.1, p<0.01\right)$, a diet $\times$ injection interaction $\left(F_{(1,40)}=4.8, p<0.05\right)$, and an injection $\times$ diet $\times$ age interaction $\left(F_{(1,40)}=4.1, p=0.05\right)$. Moreover, the age $\times$ diet interaction was found in LiCl-injected groups $\left(F_{(1,20)}=10.5, p<0.005\right)$ but not in saline-injected groups $\left(F_{(1,20)}=1.9, p>1\right)$. The diet $\times$ injection interaction was found in juvenile $\left(\mathrm{F}_{(1,20)}=4.8, p<0.05\right)$ but not in adult $(F<1, p>$ $0.1)$ groups. Post hoc analyses indicated that $\mathrm{LiCl}$ injection in the jHFD group induced a significantly higher increase in the corticosterone level than in all the other groups $(p<0.001$; Fig. $3 A)$, which did not differ from one another $(p>0.1)$. These results indicate that HFD intake enhances $\mathrm{LiCl}$-induced corticosterone release specifically after juvenile exposure.

Interestingly, a strong positive correlation appeared between corticosterone levels and the number of c-Fos- or Egr-1 positive cells in the BLA in juvenile groups $(n=24$; c-Fos: $r=0.66, Z=$ 3.7, $p=0.0003$, Fig. $3 B$; Egr- $1 r=0.60, Z=3.2, p=0.0014$; data not shown) but not in adult groups $(n=24 ; r<0.15, Z<0.6, p>$ 0.5 for both c-Fos and Egr-1). In juvenile groups, this correlation 
A

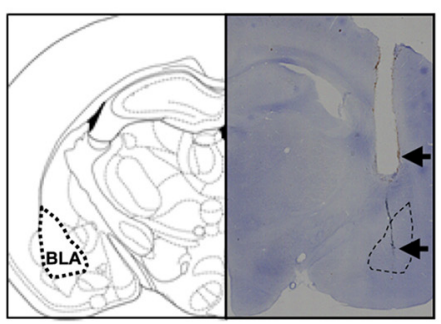

B

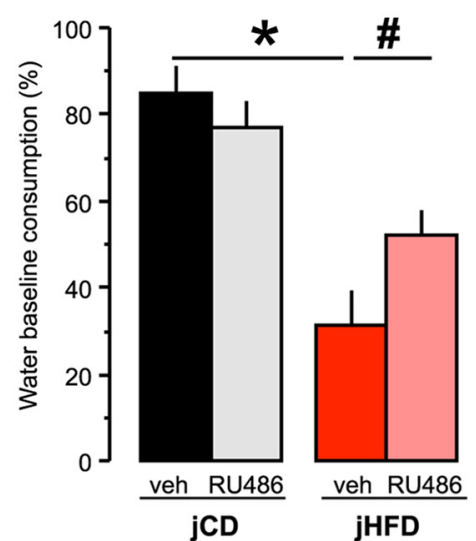

C

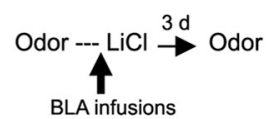

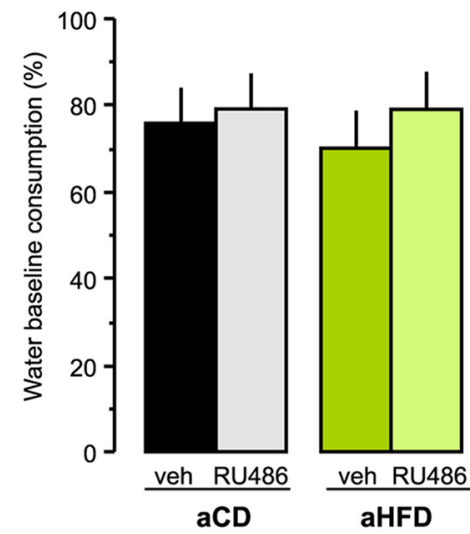

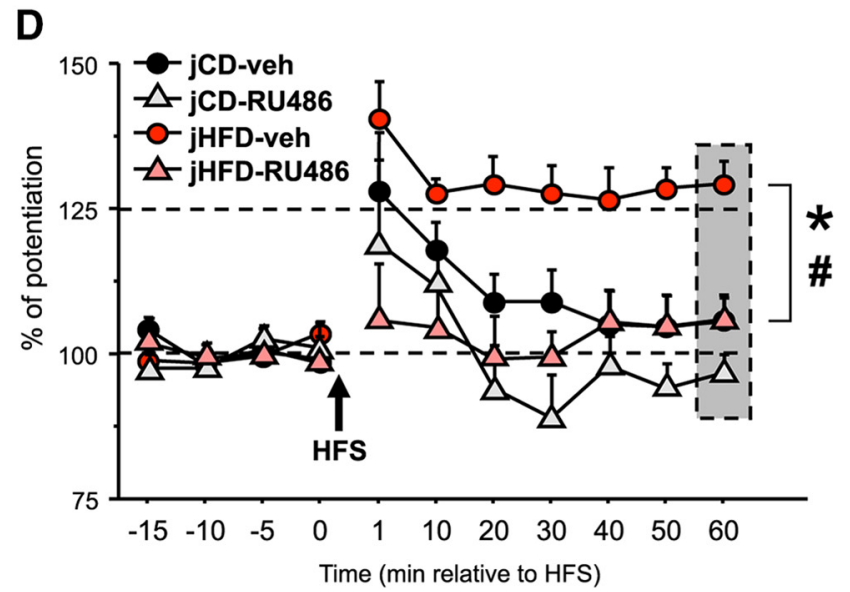

E

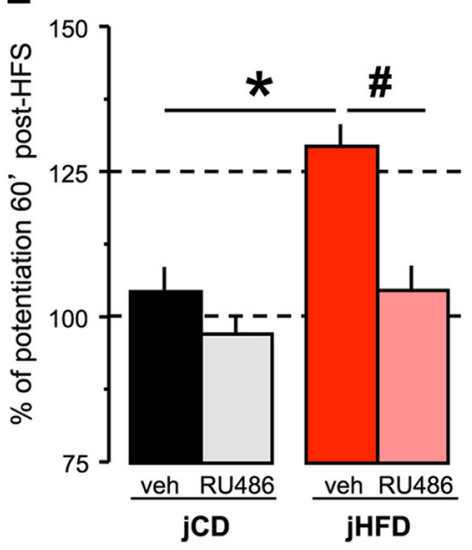

Figure 4. Juvenile HFD-induced enhancement of emotional memory and basolateral amygdala synaptic plasticity is alleviated by blockade of glucocorticoid receptors. $A$, Photomicrograph illustrating representative placement of cannula (top arrow) and needle (bottom arrow) tips terminating in the BLA. $\boldsymbol{B}, \boldsymbol{C}$, Effects of juvenile (B) or adult (C) HFD consumption on COA memory assessed $3 \mathrm{~d}$ after acquisition during which RU486 ( $3 \mathrm{ng} / 0.25 \mu \mathrm{l}$ per side) or vehicle (veh; $0.25 \mu$ l per side) was infused in the BLA immediately before LiCl injection (jCD-veh, $n=11 ; j C D$-RU 486 , $n=12 ;$ jHFD-veh, $n=7 ;$ jHFD-RU486, $n=11$; aCD-veh, $n=7$; aCD-RU486, $n=8$; aHFD-veh, $n=11$; aHFD-RU486, $n=10$ ). $D$, Effects of juvenile HFD consumption on long-term potentiation in the BLA induced by high-frequency stimulation (HFS; 100 pulses at $200 \mathrm{~Hz}$ ) of entorhinal cortex after intraperitoneal injection of RU486 $(50 \mathrm{mg} / \mathrm{kg})$ or vehicle (jCD-veh, $n=10 ; j \mathrm{CD}-\mathrm{RU} 486, n=$ $7 ;$ jHFD-veh, $n=7$; jHFD-RU486, $n=6$ ). $E$, Details of long-term potentiation in the BLA $1 \mathrm{~h}$ after HFS (corresponding to the shaded area in $C$. ${ }^{*} p<0.05$ compared with the jCD-veh group; ${ }^{\#} p<$ 0.05 compared with the jHFD-veh group.

was present in the LiCl-treated groups (c-Fos: $r=0.73, Z=2.8$, $p=0.006$; Egr-1: $r=0.61, Z=2.1, p=0.03)$ but not in the $\mathrm{NaCl}$-injected groups $(r<0.23, Z<0.7, p>0.5$ for both $\mathrm{c}$-Fos and Egr-1). This suggests that, in jHFD rats, BLA activation after $\mathrm{LiCl}$ is directly linked to corticosterone release.

To better characterize the effect of jHFD intake on corticosterone response to $\mathrm{LiCl}$ injection, we compared the time course of plasma corticosterone levels in the jHFD and jCD groups (Fig. $3 C$ ). Moreover, the levels of circulating corticosterone previously obtained were abnormally high (Fig. $3 A$ ), likely because of anesthesia (Vahl et al., 2005). To avoid this effect, blood samples were collected from a tail nick without anesthesia. Repeated-measures ANOVA indicated a close to significant diet $\times$ time interaction $\left(F_{(3,36)}=2.7 p=0.06\right)$. Additional analyses indicated no difference before, at the peak $30 \mathrm{~min}$ after injection, or at near basal levels 180 min after $\mathrm{LiCl}$ injection $(p>0.1)$ but showed significantly higher corticosterone levels in the jHFD group 90 min after $\mathrm{LiCl}$ injection ( $p=0.05$; Fig. $3 C$ ). The AUC was significantly higher for the $\mathrm{jHFD}$ group compared with the $\mathrm{jCD}$ group $\left(32,651 \pm 5086\right.$ vs $\left.18,909 \pm 3789 ; t_{(12)}=2.2, p=0.05\right)$. These data indicate a protracted corticosterone release in response to $\mathrm{LiCl}$ in the jHFD group.
To investigate the generality of this effect, we used restraint stress, another condition known to activate the HPA axis (Vahl et al., 2005). A significant diet $\times$ time effect was found $\left(F_{(3,39)}=\right.$ $3.4, p<0.05$; Fig. $3 D$ ). A strong increase in corticosterone levels was observed in both groups at $30 \mathrm{~min}$, whereas corticosterone levels decreased at 90 min for the jCD group but not for the jHFD group. Higher corticosterone levels in the $\mathrm{jHFD}$ group were present at $90 \mathrm{~min}$ and, to a lesser extent, at $180 \mathrm{~min}$ after restraint stress $(p<0.004$ and $p<0.02$, respectively, Fig. $3 D)$. The AUC was significantly higher for the jHFD group compared with the jCD group $\left(28,932 \pm 1136\right.$ vs $19,343 \pm 1273 ; t_{(13)}=5.3, p<$ $0.001)$.

We then examined whether jHFD intake could modify the natural fluctuation of the corticosterone level throughout the day by collecting blood samples every 2-4 h from 7:00 A.M. to 11:00 P.M. There was a highly significant time effect $\left(F_{(6,90)}=16.2, p<\right.$ $0.001)$ confirming circadian rhythm of corticosterone secretion but no diet $\times$ time interaction $(F<1)$ indicating that jHFD did not affect the HPA axis circadian activity (data not shown). Finally, jHFD exposure did not modify the adrenal gland (weight: jHFD rats, $49 \pm 1.5 \mathrm{~g}$; jCD rats, $51 \pm 3.1 \mathrm{~g}$; $t_{(22)}<1$ ), confirming $\mathrm{jHFD}$ consumption did not lead to chronic overactivation of the 
HPA axis. These results indicate that jHFD exposure induced a protracted stress-induced corticosterone release without altering basal corticosterone levels.

\section{GR activation in basolateral amygdala mediates juvenile HFD-induced enhancement of odor aversion memory}

We then assessed whether blocking corticosterone action by specific blockade of GR in the BLA with the antagonist RU486 could attenuate the enhancement of COA memory in jHFD-fed rats without affecting aHFD-fed rats.

In juvenile exposed rats, all animals similarly drank the odorized water during acquisition without any effect of diet (unpaired $t$ test on percentage of water baseline: $t_{(39)}<1$; data not shown). BLA infusion of vehicle or RU486 (3 ng) was performed $30 \mathrm{~min}$ after odorized water consumption and immediately before gastric malaise induction. During the test, all groups decreased their consumption of odorized water (compared with water baseline: for each group, $t>2.3, p<0.05$ ), demonstrating a conditioned aversion. The percentage of odorized water intake measured during the test with respect to water baseline consumption is shown in Figure $4 B$. Importantly, the drug $\times$ diet interaction was significant $\left(F_{(1,37)}=4.7, p=0.036\right)$, which indicates that RU486 dampened the aversion strength depending on the diet. jHFDveh rats differed from $j \mathrm{CD}$-veh rats $(p<0.001)$, replicating previous data obtained with unoperated rats. More importantly, the GR antagonist decreased the aversion in jHFD rats (jHFD-veh vs jHFD-RU, $p=0.037$; Fig. $4 B$ ), whereas it did not affect the odor aversion in jCD rats $(p=0.39, \mathrm{jCD}$-veh vs jCD-RU). Moreover, the GR antagonist did not totally reverse the aversion of $\mathrm{jHFD}$ rats as these rats still differed from jCD-veh and jCD-RU rats $(p<0.01)$.

In adult exposed rats, all animals similarly drank scented water during acquisition without any effect of diet (percentage of water baseline: $t_{(34)}<1, p=0.23$; data not shown). During the test, all groups similarly decreased their consumption of odorized water (compared with water baseline: for each group, $t>3.1, p<$ 0.05 ) without any effect of diet and drug (drug $\times$ diet interaction: $F_{(1,32)}=0.11, p=0.74$; Fig. $\left.4 C\right)$. This indicates that the GR antagonist had no effect on the aversion strength in aHFD-fed rats.

\section{GR activation mediates juvenile HFD-induced enhancement of long-term potentiation in the basolateral amygdala}

Synaptic plasticity, specifically LTP, is thought to be the underlying cellular mechanism for learning and memory processes in the brain (Bliss and Collingridge, 1993). We then assessed whether 3 months of HFD consumption since weaning enhanced LTP in BLA and whether blocking GR with RU486 (50 mg/kg) could restore normal levels of BLA plasticity in jHFD-fed rats.

Baseline amplitude before high-frequency stimulation did not differ between groups ( $F \leq 1 ; p>0.1$ for diet, drug, and interaction effects). A two-way repeated-measures ANOVA on the poststimulation recording showed a significant diet $X$ drug interaction on the levels of potentiation in the $\operatorname{BLA}\left(F_{(1,26)}=\right.$ 3.9, $p=0.05$; Fig. $4 D$ ). Post hoc analysis showed that the jHFDveh group significantly differed from all the other groups $(p<$ $0.001)$. One hour after stimulation, the level of potentiation in the jHFD-veh group $(129 \pm 4 \%)$ was still significantly higher than those of the other groups $(p<0.004 ; 101 \pm 6,97 \pm 3$, and $105 \pm$ $4 \%$ for jCD-veh, jCD-RU486, and jHFD-RU486; Fig. 4E). This level was different from the baseline level only in the jHFD-veh group $\left(t_{(6)}=4.6, p<0.01\right.$; other groups: $\left.t<1.7, p>0.1\right)$.

Altogether, these results show that jHFD increases LTP in the BLA and that this enhancement is dependent on GR activation.

\section{Discussion}

We demonstrate that juvenile consumption of HFD, from weaning to adulthood, enhances long-term aversive memories as assessed by odor-malaise and tone-shock associations. We also found that juvenile HFD exposure prolongs the release of glucocorticoids after aversive stimuli, enhancing BLA activation. These effects are not observed when HFD consumption for a similar duration was confined to adulthood. Interestingly, blockade of GR activation is sufficient to dampen the effects of juvenile HFD intake on increased aversive memory as well as on synaptic plasticity in the BLA.

Our study first shows that juvenile, but not adult, HFD exposure enhances both odor aversion and auditory fear memories. Few studies have investigated the effects of HFD on emotional memory. Our results are consistent with studies showing that genetic mouse models of obesity, for which overweight starts very early after weaning, enhanced flavor aversion memory (Thompson et al., 1993, Ohta et al., 2003), whereas HFD-induced obese mice at adulthood did not affect auditory fear memory (Heyward et al., 2012). However, our results seem contradictory to other studies showing impaired fear memory after early exposure to HFD (Hwang et al., 2010; Yamada-Goto et al., 2012). These studies used more drastic HFD conditions (60\% kcal from lipids instead of $45 \% \mathrm{kcal}$ in our study), which have been shown to influence the effect of HFD on cognitive processes (Pistell et al., 2010). More importantly, the discrepancy seems to be linked to a major procedural difference. In our conditions, fear conditioning leads to high fear response to the cue but not to the context, whereas these studies used delay fear conditioning resulting in predominant contextual fear memory. In contrast to auditory fear conditioning, contextual fear conditioning greatly depends on hippocampal integrity (Rudy et al., 2002; for review, see Maren et al., 2013;), and chronic HFD intake has a clear deleterious effect on hippocampal-dependent plasticity and memory (for review, see Kanoski and Davidson, 2011), in particular after juvenile HFD exposure (Boitard et al., 2012, 2014; ValladolidAcebes et al., 2013). Interestingly, using trace fear conditioning, a very recent report indicates that cafeteria diet-fed rats froze less to the conditioning context but displayed enhanced freezing to the cue compared with chow-fed rats (Reichelt et al., 2015). Altogether, these results suggest that juvenile HFD consumption has a bidirectional effect on learning and memory processes, enhancing amygdala-dependent, cue-based memory while impairing hippocampal-dependent contextual memory.

Our study also brings out new findings on the effects of HFD on emotional memory. Albeit affecting long-term aversive memory, juvenile exposure to HFD has no effect on short-term memory. This rules out an effect of jHFD on CS and US perception (also supported by the normal postshock freezing) and suggests a specific effect on memory consolidation. Memory consolidation requires synthesis of new proteins (Davis and Squire, 1984; Dudai, 2004), and inhibiting protein synthesis in the BLA specifically impairs long-term memory of COA and auditory fear conditioning without affecting short-term memory (Schafe et al., 2000; Desgranges et al., 2008). Similarly, persistent forms of synaptic plasticity, such as the late phase of LTP, critically depend on the synthesis of new proteins (Lynch et al., 2007; Abraham and Williams, 2008). Interestingly, only jHFD-fed rats display the late phase of LTP in the BLA $1 \mathrm{~h}$ after high-frequency stimulation (Fig. 4D). In parallel, we show in the BLA, but not in the CeA, of these animals a higher protein expression of the immediate-early genes c-Fos and Egr-1 after gastric malaise. This corroborates a 
recent report indicating that chronic high-fat feeding in mice increases plasticity-related (BDNF and phospho-CREB) protein levels in the amygdala (Sharma et al., 2013) and suggests that juvenile exposure to HFD enhances protein synthesis after BLA stimulation, leading to long-term synaptic and behavioral changes.

To determine how HFD exposure during adolescence leads to enhanced consolidation of emotional memories, we investigated the role of glucocorticoids, since previous research has shown that GR activation in the BLA modulates consolidation of emotional memory as well as LTP in lean animals (Roozendaal and McGaugh, 1997; Miranda et al., 2008; Sarabdjitsingh et al., 2012). Moreover, adolescence is a decisive period for maturation of the HPA axis (Spear, 2000; McCormick and Mathews, 2010; Foilb et al., 2011), and previous reports indicate that chronic HFD exposure can alter HPA axis activity (Tannenbaum et al., 1998; Legendre and Harris, 2006; Sharma and Fulton, 2013). Finally, expression of Egr-1 (our results), BDNF, and phospho-CREB (Sharma et al., 2013), which are enhanced in the amygdala after HFD exposure, are molecular targets of activated GR (Revest et al., 2005, 2014; Chen et al., 2012). We found that jHFD induces a protracted $\mathrm{LiCl}$-induced corticosterone release that correlates with BLA activation. Interestingly, such changes are not present when HFD exposure occurs at adulthood. Finally, blocking GR activation in the BLA attenuates the stronger aversive memory of jHFD-fed rats but has no effect in aHFD-fed rats, and systemic GR blockade restores normal synaptic plasticity in the BLA of $\mathrm{jHFD}$-fed rats. These findings indicate that prolonged corticosterone release mediates, at least in part, the enhancement of both long-term aversive memory and amygdala synaptic plasticity through a longer-lasting GR activation.

In our previous studies, we demonstrated an increased susceptibility of the juvenile period to the effect of HFD on hippocampal-dependent plasticity and memory (Boitard et al., 2012, 2014; Valladolid-Acebes et al., 2013). Here, we generalize this notion to another memory system. However, there are two noticeable differences between the effects of jHFD on hippocampal and amygdala memory systems. First, we recently demonstrated that 1.5-2 months of juvenile HFD exposure was sufficient to affect hippocampal function (Boitard et al., 2012, 2014), whereas we find here that 3 months of HFD exposure starting at weaning is necessary to affect amygdala function. The faster impact of HFD on hippocampus could be related to the increased permeability of the blood-brain barrier specifically observed in this brain area in obese animals (Kanoski et al., 2010; Davidson et al., 2012). According to the hippocampal regulation of the HPA axis (Ulrich-Lai and Herman, 2009) and the role played by glucocorticoids in HFD-induced amygdala changes, it remains to be determined whether the early hippocampal alterations participate in the change of amygdala function occurring afterward. Second, as stated previously, juvenile HFD exposure induced an impairment of hippocampal function but an enhancement of amygdala function. This bidirectional effect on hippocampal and amygdala functions was previously reported in other situations such as chronic stress (Sandi and Pinelo-Nava, 2007; Lupien et al., 2009), aging (Misanin et al., 2002; Lister and Barnes, 2009), models of Alzheimer's disease (España et al., 2010), or PTSD (Kaouane et al., 2012), which are all characterized by deregulation of the HPA axis activity (Sapolsky et al., 1986; Sandi and Pinelo-Nava, 2007; Kaouane et al., 2012). In particular, PTSD is characterized by enduring and maladaptive emotional memory (Elzinga and Bremner, 2002; Layton and Krikorian, 2002), and some authors suggest that individuals with PTSD show over-consolidation of emotional memory (Mahan and
Ressler, 2012). Interestingly, in humans, obesity has been associated with a higher prevalence of PTSD (Pagoto et al., 2012; Johannessen and Berntsen, 2013), particularly in obese adolescents (Britz et al., 2000; Perkonigg et al., 2009). Based on our results suggesting that juvenile obesity enhances emotional memories and given the fact that childhood and adolescent trauma predisposes individuals to develop PTSD (for review, see Gerson and Rappaport, 2013), future experiments are needed to determine whether and how juvenile obesity could also predispose to develop PTSD.

\section{References}

Abraham WC, Williams JM (2008) LTP maintenance and its protein synthesis-dependence. Neurobiol Learn Mem 89:260-268. CrossRef Medline

Andersen SL (2003) Trajectories of brain development: point of vulnerability or window of opportunity? Neurosci Biobehav Rev 27:3-18. CrossRef Medline

Blanchard RJ, Blanchard DC (1969) Crouching as an index of fear. J Comp Physiol Psychol 67:370-375. CrossRef Medline

Bliss TV, Collingridge GL (1993) A synaptic model of memory: long-term potentiation in the hippocampus. Nature 361:31-39. CrossRef Medline

Boitard C, Etchamendy N, Sauvant J, Aubert A, Tronel S, Marighetto A, Layé S, Ferreira G (2012) Juvenile, but not adult exposure to high-fat diet impairs relational memory and hippocampal neurogenesis in mice. Hippocampus 22:2095-2100. CrossRef Medline

Boitard C, Cavaroc A, Sauvant J, Aubert A, Castanon N, Layé S, Ferreira G (2014) Impairment of hippocampal-dependent memory induced by juvenile high-fat diet intake is associated with enhanced hippocampal inflammation in rats. Brain Behav Immun 40:9-17. CrossRef Medline

Britz B, Siegfried W, Ziegler A, Lamertz C, Herpertz-Dahlmann BM, Remschmidt H, Wittchen HU, Hebebrand J (2000) Rates of psychiatric disorders in a clinical study group of adolescents with extreme obesity and in obese adolescents ascertained via a population based study. Int J Obes Relat Metab Disord 24:1707-1714. CrossRef Medline

Chen DY, Bambah-Mukku D, Pollonini G, Alberini CM (2012) Glucocorticoid receptors recruit the CaMKII $\alpha$-BDNF-CREB pathways to mediate memory consolidation. Nat Neurosci 15:1707-1714. CrossRef Medline

Cserjési R, Molnár D, Luminet O, Lénárd L (2007) Is there any relationship between obesity and mental flexibility in children? Appetite 49:675-678. CrossRef Medline

Davidson TL, Monnot A, Neal AU, Martin AA, Horton JJ, Zheng W (2012) The effects of a high-energy diet on hippocampal-dependent discrimination performance and blood-brain barrier integrity differ for dietinduced obese and diet-resistant rats. Physiol Behav 107:26-33. CrossRef Medline

Davis HP, Squire LR (1984) Protein synthesis and memory: a review. Psychol Bull 96:518-559. CrossRef Medline

Desgranges B, Lévy F, Ferreira G (2008) Anisomycin infusion in amygdala impairs consolidation of odor aversion memory. Brain Res 1236:166175. CrossRef Medline

Dixon JB, Browne JL, Lambert GW, Jones KM, Reddy P, Pouwer F, Speight J (2013) Severely obese people with diabetes experience impaired emotional well-being associated with socioeconomic disadvantage: results from diabetes MILES-Australia. Diabetes Res Clin Pract 101:131-140. CrossRef Medline

Donley MP, Schulkin J, Rosen JB (2005) Glucocorticoid receptor antagonism in the basolateral amygdala and ventral hippocampus interferes with long-term memory of contextual fear. Behav Brain Res 164:197-205. CrossRef Medline

Dudai Y (2004) The neurobiology of consolidations, or, how stable is the engram? Annu Rev Psychol 55:51-86. CrossRef Medline

Elzinga BM, Bremner JD (2002) Are the neural substrates of memory the final common pathway in posttraumatic stress disorder (PTSD)? J Affect Disord 70:1-17. CrossRef Medline

España J, Giménez-Llort L, Valero J, Miñano A, Rábano A, RodriguezAlvarez J, LaFerla FM, Saura CA (2010) Intraneuronal beta-amyloid accumulation in the amygdala enhances fear and anxiety in Alzheimer's disease transgenic mice. Biol Psychiatry 67:513-521. CrossRef Medline

Fanselow MS, Gale GD (2003) The amygdala, fear, and memory. Ann N Y Acad Sci 985:125-134. CrossRef Medline 
Ferreira G, Gutiérrez R, De La Cruz V, Bermúdez-Rattoni F (2002) Differential involvement of cortical muscarinic and NMDA receptors in shortand long-term taste aversion memory. Eur J Neurosci 16:1139-1145. CrossRef Medline

Ferreira G, Ferry B, Meurisse M, Lévy F (2006) Forebrain structures specifically activated by conditioned taste aversion. Behav Neurosci 120:952962. CrossRef Medline

Ferry B, Wirth S, Di Scala G (1999) Functional interaction between entorhinal cortex and basolateral amygdala during trace conditioning of odor aversion in the rat. Behav Neurosci 113:118-125. CrossRef Medline

Finsterwald C, Alberini CM (2014) Stress and glucocorticoid receptordependent mechanisms in long-term memory: from adaptive responses to psychopathologies. Neurobiol Learn Mem 112:17-29. CrossRef Medline

Foilb AR, Lui P, Romeo RD (2011) The transformation of hormonal stress responses throughout puberty and adolescence. J Endocrinol 210:391398. CrossRef Medline

Francis H, Stevenson R (2013) The longer-term impacts of Western diet on human cognition and the brain. Appetite 63:119-128. CrossRef Medline

Gerson R, Rappaport N (2013) Traumatic stress and posttraumatic stress disorder in youth: recent research findings on clinical impact, assessment, and treatment. J Adolesc Health 52:137-143. CrossRef Medline

Hawkins MA, Stewart JC (2012) Do negative emotional factors have independent associations with excess adiposity? J Psychosom Res 73:243-250. CrossRef Medline

Heyward FD, Walton RG, Carle MS, Coleman MA, Garvey WT, Sweatt JD (2012) Adult mice maintained on a high-fat diet exhibit object location memory deficits and reduced hippocampal SIRT1 gene expression. Neurobiol Learn Mem 98:25-32. CrossRef Medline

Hwang LL, Wang CH, Li TL, Chang SD, Lin LC, Chen CP, Chen CT, Liang KC, Ho IK, Yang WS, Chiou LC (2010) Sex differences in high-fat dietinduced obesity, metabolic alterations and learning, and synaptic plasticity deficits in mice. Obesity (Silver Spring) 18:463-469. CrossRef Medline

Johannessen KB, Berntsen D (2013) Losing the symptoms: weight loss and decrease in posttraumatic stress disorder symptoms. J Clin Psychol 69: 655-660. CrossRef Medline

Kanoski SE, Davidson TL (2011) Western diet consumption and cognitive impairment: links to hippocampal dysfunction and obesity. Physiol Behav 103:59-68. CrossRef Medline

Kanoski SE, Zhang Y, Zheng W, Davidson TL (2010) The effects of a highenergy diet on hippocampal function and blood-brain barrier integrity in the rat. J Alzheimers Dis 21:207-219. CrossRef Medline

Kaouane N, Porte Y, Vallée M, Brayda-Bruno L, Mons N, Calandreau L, Marighetto A, Piazza PV, Desmedt A (2012) Glucocorticoids can induce PTSD-like memory impairments in mice. Science 335:1510-1513. CrossRef Medline

Koh MT, Clarke SN, Spray KJ, Thiele TE, Bernstein IL (2003) Conditioned taste aversion memory and c-Fos induction are disrupted in RIIbeta-protein kinase A mutant mice. Behav Brain Res 143:57-63. CrossRef Medline

Layton B, Krikorian R (2002) Memory mechanisms in posttraumatic stress disorder. J Neuropsychiatry Clin Neurosci 14:254-261. CrossRef Medline

LeDoux J (2003) The emotional brain, fear, and the amygdala. Cell Mol Neurobiol 23:727-738. CrossRef Medline

Legendre A, Harris RB (2006) Exaggerated response to mild stress in rats fed high-fat diet. Am J Physiol Regul Integr Comp Physiol 291:R1288-R1294. CrossRef Medline

Li Y, Dai Q, Jackson JC, Zhang J (2008) Overweight is associated with decreased cognitive functioning among school-age children and adolescents. Obesity (Silver Spring) 16:1809-1815. CrossRef Medline

Lister JP, Barnes CA (2009) Neurobiological changes in the hippocampus during normative aging. Arch Neurol 66:829-833. CrossRef Medline

Lupien SJ, McEwen BS, Gunnar MR, Heim C (2009) Effects of stress throughout the lifespan on the brain, behaviour and cognition. Nat Rev Neurosci 10:434-445. CrossRef Medline

Lynch G, Rex CS, Gall CM (2007) LTP consolidation: substrates, explanatory power, and functional significance. Neuropharmacology 52:12-23. CrossRef Medline

Mahan AL, Ressler KJ (2012) Fear conditioning, synaptic plasticity and the amygdala: implications for posttraumatic stress disorder. Trends Neurosci 35:24-35. CrossRef Medline

Malnick SD, Knobler H (2006) The medical complications of obesity. QJM 99:565-579. CrossRef Medline
Marchand AR, Luck D, DiScala G (2003) Evaluation of an improved automated analysis of freezing behaviour in rats and its use in trace fear conditioning. J Neurosci Methods 126:145-153. CrossRef Medline

Maren S (2005) Synaptic mechanisms of associative memory in the amygdala. Neuron 47:783-786. CrossRef Medline

Maren S, Phan KL, Liberzon I (2013) The contextual brain: implications for fear conditioning, extinction and psychopathology. Nat Rev Neurosci 14:417-428. CrossRef Medline

McCormick CM, Mathews IZ (2010) Adolescent development, hypothalamicpituitary-adrenal function, and programming of adult learning and memory. Prog Neuropsychopharmacol Biol Psychiatry 34:756-765. CrossRef Medline

McGaugh JL (2004) The amygdala modulates the consolidation of memories of emotionally arousing experiences. Annu Rev Neurosci 27:1-28. CrossRef Medline

Miranda MI, Quirarte GL, Rodriguez-Garcia G, McGaugh JL, Roozendaal B (2008) Glucocorticoids enhance taste aversion memory via actions in the insular cortex and basolateral amygdala. Learn Mem 15:468-476. CrossRef Medline

Misanin JR, Collins M, Rushanan S, Anderson MJ, Goodhart M, Hinderliter CF (2002) Aging facilitates long-trace taste-aversion conditioning in rats. Physiol Behav 75:759-764. CrossRef Medline

Mouly AM, Di Scala G (2006) Entorhinal cortex stimulation modulates amygdala and piriform cortex responses to olfactory bulb inputs in the rat. Neuroscience 137:1131-1141. CrossRef Medline

Nilsson LG, Nilsson E (2009) Overweight and cognition. Scand J Psychol 50:660-667. CrossRef Medline

Ogden CL, Carroll MD, Kit BK, Flegal KM (2012) Prevalence of obesity and trends in body mass index among US children and adolescents, 1999_ 2010. JAMA 307:483-490. CrossRef Medline

Ohta R, Shigemura N, Sasamoto K, Koyano K, Ninomiya Y (2003) Conditioned taste aversion learning in leptin-receptor-deficient $\mathrm{db} / \mathrm{db}$ mice. Neurobiol Learn Mem 80:105-112. CrossRef Medline

Pagoto SL, Schneider KL, Bodenlos JS, Appelhans BM, Whited MC, Ma Y, Lemon SC (2012) Association of post-traumatic stress disorder and obesity in a nationally representative sample. Obesity 20:200-205. CrossRef Medline

Pasquali R, Vicennati V, Cacciari M, Pagotto U (2006) The hypothalamicpituitary-adrenal axis activity in obesity and the metabolic syndrome. Ann N Y Acad Sci 1083:111-128. CrossRef Medline

Paxinos G, Watson C (1998) The rat brain in stereotaxic coordinates. San Diego: Academic.

Perkonigg A, Owashi T, Stein MB, Kirschbaum C, Wittchen HU (2009) Posttraumatic stress disorder and obesity: evidence for a risk association. Am J Prev Med 36:1-8. CrossRef Medline

Pistell PJ, Morrison CD, Gupta S, Knight AG, Keller JN, Ingram DK, BruceKeller AJ (2010) Cognitive impairment following high fat diet consumption is associated with brain inflammation. J Neuroimmunol 219: 25-32. CrossRef Medline

Reichelt AC, Maniam J, Westbrook RF, Morris MJ (2015) Dietary-induced obesity disrupts trace fear conditioning and decreases hippocampal reelin expression. Brain Behav Immun 43:68-75. CrossRef Medline

Revest JM, Di Blasi F, Kitchener P, Rougé-Pont F, Desmedt A, Turiault M, Tronche F, Piazza PV (2005) The MAPK pathway and Egr-1 mediate stress-related behavioral effects of glucocorticoids. Nat Neurosci 8:664672. CrossRef Medline

Revest JM, Le Roux A, Roullot-Lacarrière V, Kaouane N, Vallée M, Kasanetz F, Rougé-Pont F, Tronche F, Desmedt A, Piazza PV (2014) BDNF-TrkB signaling through Erk1/2MAPK phosphorylation mediates the enhancement of fear memory induced by glucocorticoids. Mol Psychiatry 19: 1001-1009. CrossRef Medline

Richard EM, Helbling JC, Tridon C, Desmedt A, Minni AM, Cador M, Pourtau L, Konsman JP, Mormède P, Moisan MP (2010) Plasma transcortin influences endocrine and behavioral stress responses in mice. Endocrinology 151:649-659. CrossRef Medline

Roozendaal B, McGaugh JL (1997) Glucocorticoid receptor agonist and antagonist administration into the basolateral but not central amygdala modulates memory storage. Neurobiol Learn Mem 67:176-179. CrossRef Medline

Roozendaal B, McEwen BS, Chattarji S (2009) Stress, memory and the amygdala. Nat Rev Neurosci 10:423-433. CrossRef Medline

Rudy JW, Barrientos RM, O'Reilly RC (2002) Hippocampal formation supports conditioning to memory of a context. Behav Neurosci 116:530 -538. CrossRef Medline 
Sandi C, Pinelo-Nava MT (2007) Stress and memory: behavioral effects and neurobiological mechanisms. Neural Plast 2007:78970. CrossRef Medline

Sapolsky RM, Krey LC, McEwen BS (1986) The adrenocortical axis in the aged rat: impaired sensitivity to both fast and delayed feedback inhibition. Neurobiol Aging 7:331-335. CrossRef Medline

Sarabdjitsingh RA, Kofink D, Karst H, de Kloet ER, JoëlsM (2012) Stressinduced enhancement of mouse amygdalar synaptic plasticity depends on glucocorticoid and ss-adrenergic activity. PLoS One 7:e42143. CrossRef Medline

Schafe GE, Atkins CM, Swank MW, Bauer EP, Sweatt JD, LeDoux JE (2000) Activation of ERK/MAP kinase in the amygdala is required for memory consolidation of pavlovian fear conditioning. J Neurosci 20:8177-8187. Medline

Sellbom KS, Gunstad J (2012) Cognitive function and decline in obesity. J Alzheimers Dis 30 [Suppl 2]:S89-S95.

Sevelinges Y, Desgranges B, Ferreira G (2009) The basolateral amygdala is necessary for the encoding and the expression of odor memory. Learn Mem 16:235-242. CrossRef Medline

Sharma S, Fulton S (2013) Diet-induced obesity promotes depressive-like behaviour that is associated with neural adaptations in brain reward circuitry. Int J Obes (Lond) 37:382-389. CrossRef Medline

Sharma S, Fernandes MF, Fulton S (2013) Adaptations in brain reward circuitry underlie palatable food cravings and anxiety induced by high-fat diet withdrawal. Int J Obes (Lond) 37:1183-1191. CrossRef Medline

Spear LP (2000) The adolescent brain and age-related behavioral manifestations. Neurosci Biobehav Rev 24:417-463. CrossRef Medline

Tannenbaum BM, Brindley DN, Tannenbaum GS, Dallman MF, McArthur MD, Meaney MJ (1997) High-fat feeding alters both basal and stressinduced hypothalamic-pituitary-adrenal activity in the rat. Am J Physiol 273:E1168-E1177. Medline

Thompson CI, Margules DL, Kreider JW, Boha SP, Rejer RE Jr, Quirey RA, Reitz JA (1993) Propensity to form conditioned taste aversions aug- ments anorexia in obese (ob/ob) mice with B16 melanoma. Behav Neurosci 107:786-798. CrossRef Medline

Ulrich-Lai YM, Herman JP (2009) Neural regulation of endocrine and autonomic stress responses. Nat Rev Neurosci 10:397-409. CrossRef Medline

Vahl TP, Ulrich-Lai YM, Ostrander MM, Dolgas CM, Elfers EE, Seeley RJ, D'Alessio DA, Herman JP (2005) Comparative analysis of ACTH and corticosterone sampling methods in rats. Am J Physiol Endocrinol Metab 289:E823-E828. CrossRef Medline

Valladolid-Acebes I, Fole A, Martín M, Morales L, Cano MV, Ruiz-Gayo M, Del Olmo N (2013) Spatial memory impairment and changes in hippocampal morphology are triggered by high-fat diets in adolescent mice. Is there a role of leptin? Neurobiol Learn Mem 106:18-25. CrossRef Medline

Vendruscolo LF, Gueye AB, Darnaudéry M, Ahmed SH, Cador M (2010) Sugar overconsumption during adolescence selectively alters motivation and reward function in adult rats. PLoS One 5:e9296. CrossRef Medline

Vouimba RM, Yaniv D, Diamond D, Richter-Levin G (2004) Effects of inescapable stress on LTP in the amygdala versus the dentate gyrus of freely behaving rats. Eur J Neurosci 19:1887-1894. CrossRef Medline

Yamada-Goto N, Katsuura G, Ochi Y, Ebihara K, Kusakabe T, Hosoda K, Nakao K (2012) Impairment of fear-conditioning responses and changes of brain neurotrophic factors in diet-induced obese mice. J Neuroendocrinol 24:1120-1125. CrossRef Medline

Yamamoto T, Sako N, Sakai N, Iwafune A (1997) Gustatory and visceral inputs to the amygdala of the rat: conditioned taste aversion and induction of c-fos-like immunoreactivity. Neurosci Lett 226:127-130. CrossRef Medline

Yaniv D, Vouimba RM, Diamond DM, Richter-Levin G (2003) Simultaneous induction of long-term potentiation in the hippocampus and the amygdala by entorhinal cortex activation: mechanistic and temporal profiles. Neuroscience 120:1125-1135. CrossRef Medline 